\title{
A Research on the Relationship Between Brand Experience and Brand Name With Customer Satisfaction
}

\author{
Selda Uca Özer, Bilge Çavuşgil Köse \\ Trakya University, Edirne, Turkey
}

\begin{abstract}
Customer satisfaction is an important factor for companies in order to exist and survive. It is considered that brand experience and brand name have important effects on knowledge and pleasure after the sale. This study aims to determine the relationship between brand experience (sensory-affective, behavioral, and intellectual dimensions) and brand name variables with customer satisfaction. In this context, a field study was conducted on 300 students registered at Trakya University, Faculty of Economics and Administrative Sciences (Department of Business Administration) and Social Sciences Institute (Department of Business Administration). In the selection of brand, individuals who have used the said brand were chosen as a prerequisite, and therefore, a leader fast-food restaurant brand which serves in Edirne was selected. As a result of this study, both brand experiences and brand name have positively affected customer satisfaction. According to the bivariate correlation analysis, a positive and medium strength relationship was revealed between dimensions of brand experience and brand name variables with customer satisfaction.
\end{abstract}

Keywords: brand experience, brand name, customer satisfaction, fast-food restaurant, Edirne

\section{Introduction}

To provide customer satisfaction for fast-food restaurant chains which provide service on different cultural, social, and economical environment conditions may be more difficult than other elements in hospitality industry. In this case, it is possible to say that service quality perceived is sourced by differences in different cultures. Furthermore, since fast-food restaurant businesses are in a very competitive industry, to strengthen customer relations of businesses which want to survive is an increasing need. In other words, fast-food restaurant businesses which address to a rich customer portfolio should direct their interests on their customers and place customer expectations on the center of their marketing studies. All these marketing and communication studies may provide significant benefits to fast-food business in terms of customer and brand. Today, all works done to understand customer requests and needs and to satisfy these emphasize the importance of creating an additional benefit for customers. This brand value to be created will affect the development of positive attitudes by customers for the brand. Within this context, recognition of experiences and reaction of the customers on the brand name and knowing effects of these factors on customer satisfaction and pleasure gain importance.

Selda Uca Özer, assistant professor, Faculty of Economics and Administrative Sciences, Department of Business, Balkan Campus, Trakya University. Email: seldaucaozer@trakya.edu.tr.

Bilge Çavuşgil Köse, research assistant, Faculty of Economics and Administrative Sciences, Department of Business, Balkan Campus, Trakya University. 
Although there are many researches associated with very different brand components (brand equivalence, brand communication, brand identity, etc.) and brand concept on academic marketing literature during the last decade, there is not any research to reveal the relation among brand experience, brand name, and customer satisfaction. When these important aspects related with the brand are handled individually, it is noted that brand experience especially is in the concerned literature a relatively new concept, and less studies exist on the subject. On the other hand, although different studies on brand name exist, these are mostly on brand awareness and effects on brand communication.

It is considered that brand experience and brand name have important effects on knowledge and pleasure after sale. A positive brand experience will affect pleasure level of the customer after sale, increase customer satisfaction, increase buying frequency of the brand, and create loyal brand users. Similarly, brand name will facilitate the price offer assessment process presented by businesses and be effective on experiences after sale. Furthermore, brand name characteristics (images, associations, characters, semantic and audio symbols, distinctiveness, etc.) guide customer choices and affect customer satisfaction.

The design of this research was based on the absence of an academic study which examines brand experience and brand name concepts together in the concerned literature. The main purpose of the study is to determine the relationship between brand experience and brand name variables with customer satisfaction. Within this context, the preliminary condition was determined that participants on restaurant brand selection should be individuals who use and know the brand well. Therefore, the brand which is subject to the research was selected as a fast-food restaurant chain which is one of the leading companies of fast-food sector and provides service with five different branches in Edirne city. To prevent any misunderstanding on research outcomes, the name of the fast-food company discussed was not used.

Brand experience, brand name, and customer satisfaction concepts were examined theoretically first; then, a field research to determine the relationship between brand experience and brand name variables with customer satisfaction was done. Findings obtained after the analysis performed were discussed and suggestions were made for further studies.

\section{Literature Review}

Since satisfied customers realize through positive brand attitudes and redemptions, they have become an obligation for marketing (Grace \& O'Cass, 2005). Customer satisfaction is defined as "an evaluative summary of (direct) consumption experience, based on the discrepancy between prior expectation and the actual performance perceived after consumption" (Suh \& Yi, 2006, p. 146). Customer satisfaction is updated with each consuming experience appeared. In this update, it is possible to have a bigger effect of last consuming experiences. When the satisfaction that is updated dynamically in this way is exposed to a brand later, it is composed by itself and affects brand attitudes and customer loyalty through being an information resource for customer's resources. It is known that brand experience and brand name effects post redemption satisfaction experienced by the customer.

One of the most efficient ways to provide and increase customer satisfaction is to create a positive brand experience. The experience concept on marketing literature has been searched with different contents including consuming experiences, product experiences, aesthetic experiences, service experiences, shopping experiences, and customer experiences. Such experience expressions have been combined around "brand experience" concept lately (Zarantonello \& Schmitt, 2010). 
Concept of experience has been discussed by Scmitt $(1999 ; 2003)$ first within the scope of empirical marketing. Then, Brakus, Schmitt, and Zarantonello (2009, p. 53) have conceptualized brand experience as "subjective, internal consumer responses (sensations, feelings, and cognitions) and behavioral responses evoked by brand-related stimuli that are part of a brand's design and identity, pack-aging, communications, and environments". Alloza (2008, p. 374) defined brand experience as a "perception of customers on first personal contact with the brand, on quality level of personal conduct of customers or brand image reflected on commercials, in other words, perception of customers on any contact time with the brand". In other words, brand using of the customers, speaking with others about the brand, and seeking information about brand activities, promotions, etc. are also included in brand experience (Ambler, Bhattacharya, Edell, Keller, Lemon, \& Mittal, 2002).

Brand experiences vary according to the density and strength, and some brand experiences may be stronger and denser than other brand experiences. Brand experiences vary like product experiences, and some experiences may be more positive or negative. Furthermore, some brand experiences may be ineffective and continue only for a short term by realizing spontaneously, while some are designed and continue for a long time (Brakus et al., 2009).

Another important characteristic of brand experience includes different sub-dimensions. Brand experience has become focused more or less according to how many dimensions were stimulated and density of impulses that create brand experience. Dimensions of brand experience are arranged as sensorial, emotional, intellectual, and behavioral (Zarantonello \& Schmitt, 2010):

(1) Sensory dimension: It includes impulses associated with visual, auditory, gustative, olfaction, and touching;

(2) Affective dimension: It includes emotions created by the brand and emotional bound of this brand with the customer;

(3) Intellectual dimension: It includes the ability of the brand to be connected to convergent and divergent thoughts of the customer;

(4) Behavioral dimension: It includes physical experiences, life styles, and interactions created by the brand.

Today, customers are not interested in purchasing product only for their functional benefits, they also make selections regarding increasing basic experimental aspects presented by those products. As a result of this case, both academicians and pragmatists certify the importance of brand experience at developing marketing strategies for products and services through stating their great interest in brand experience term (Zarantonello \& Schmitt, 2010). Long-term brand experiences recorded on customer memory affect customer satisfaction and loyalty (Lee \& Kang, 2012). Seçkin, Zehir, and Kitapçı (2011) mentioned in their study that brand experience creates positive effects on customer satisfaction, confidence, and loyalty, and they specified that brand experience has created a confidence-based relationship between the brand and the customer, and this affects the customer satisfaction positively. Enterprises from almost all sectors need to provide a successful brand experience to their customers to build a strong brand. Although brand experience may be affected by different factors either positively or negatively, the actual purpose here is to provide unique, unforgettable, or happy experiences. In other words, customers should be taken beyond to be satisfied (Chen, 2012). 
Many researchers stated that the mostly considered and providing satisfaction element by the customers was brand name among all of the marketing factors (Aaker, 1991; Lee, 2000; Dong \& Helms, 2001; Keller, 2003; Grace \& O'Cass, 2005; Chernatony \& McDonald, 2006). One of the most efficient ways to provide customer satisfaction is to use a successful brand name. Although a brand consists of a brand name, logo, slogan, music, etc., brand name is accepted as the most central factor. To find an appropriate brand name and to transmit central theme or key, relations of a product economically are very important for enterprises (Dong \& Helms, 2001). Brand name is defined as "a name which is used to define source or character of the product and associated with one or more factors due to the product line" (Kotler, 2000, p. 396).

Brand name affects customer perceptions, plays an important role in deciding process, and is one of the most efficient factors on product or service choice (Keller, 2003; Pingjun, 2004). A good brand name contributes to the creation of high brand awareness, affects customer choices positively, and contributes to product success (Grace \& O'Cass, 2005). Brand name plays an important role in transmitting product benefits, image, and identity. Furthermore, brand name is accepted as the basis to create a brand value. Dong and Helms (2001) have revealed in their studies where they have focused on American brands in Chinese culture that brand name has an important effect on brand value.

It is alleged that the selection of brand name is one of the most important instruments to create a brand value for a new product (Keller, Heckler, \& Houston, 1998). Brand value is composed of strong, positive, and unique relations between brand names at the mind of customers and brand quality (Baltas \& Saridakis, 2009). Brand value begins with a good brand name. At the same time, brand name is an important communication tool that is used to compose powerful brand attitudes (Grace \& O'Cass, 2005). Brand name makes the product more attractive for the customers and increases their consumptions (Marjit, Beladi, \& Kabiraj, 2007).

Grace and O'Cass (2005) set forth that controlled communication and brand name have an important effect on customer satisfaction, brand attitudes, and intention of the customer about using the brand again in their studies about effects of "controlled communication, uncontrolled communication, and brand name" variables on customer satisfaction, attitudes, and purchasing intention again. Sondoh, Omar, Wahid, Ismail, and Harun (2007, p. 86) set forth that brand image as "a serial of feature and relation established with brand name of the customers". According to the authors, the marketers should orient brand image to create customer satisfaction. One of the most important determinants of brand image is "brand name". Grace and O'Cass (2005) alleged that brand name creates an important positive effect on customer satisfaction. Nezakati, Kuan, and Asgari (2011, p. 15) set forth that there is a positive relation between "product quality, product qualification, brand name, store environment, service quality, promotion, price, and customer satisfaction" variables and customer loyalty. The findings of another study that was performed by Andreani, Taniaji, and Puspitasari (2012) on McDonalds which is a fast-food restaurant set forth that customer satisfaction has a positive effect on customer loyalty. In the scope of the study, they stated that loyal customers of McDonalds will tend to purchase again, and they will also recommend the products to other customers.

In this regard, upon understanding experiences of the customers with the brand and their reflections against brand name, correlating it with other marketing factors such as satisfaction, trust, and loyalty of the customer becomes a subject that is gradually gaining importance.

\section{Method}

This study has been designed to reveal the relationship between brand experience and brand name 
variables with customer satisfaction. Population of the study is composed of "the undergraduate students of Faculty of Economic and Administrative Sciences and the postgraduate students enrolled in Business Management Department of the Social Sciences Institute in Trakya University during the academic year of 2012-2013". Number of the students registered in related institutes during the aforementioned academic year is 1,082 , and the population of the study is 300 students who are being chosen from this group of students.

\section{The Model and the Hypotheses of Study}

Proposed conceptual model in this study and the main hypotheses generated to investigate the relationships between variables are given in Figure 1.

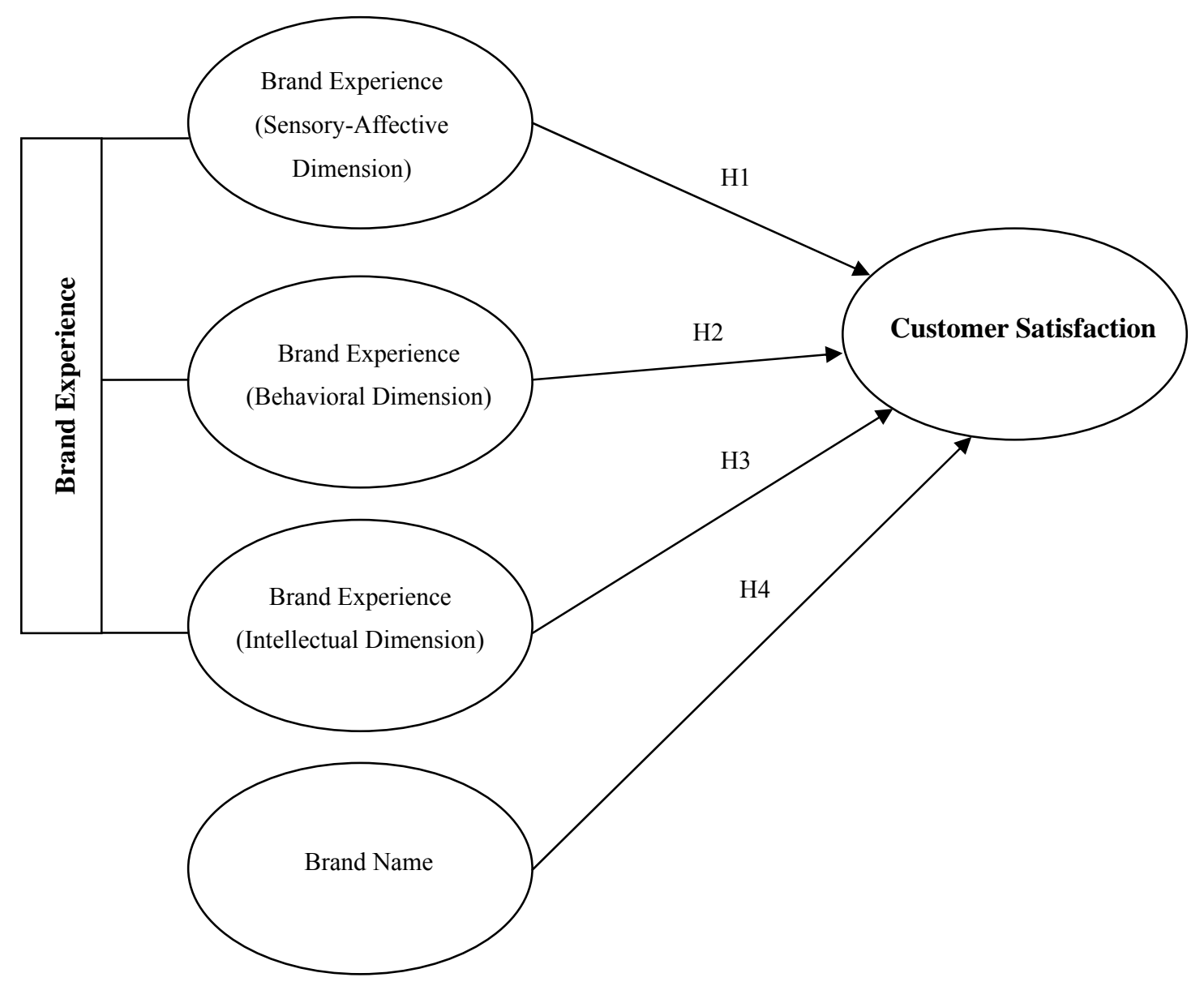

Figure 1. Conceptual model.

Hypothesis 1 (H1): There is a positive interaction between sensory-affective dimension of brand experience and the customer satisfaction.

Hypothesis 2 (H2): There is a positive interaction between behavioral dimension of brand experience and the customer satisfaction.

Hypothesis 3 (H3): There is a positive interaction between intellectual dimension of brand experience and the customer satisfaction.

Hypothesis 4 (H4): There is a positive interaction between brand name and the customer satisfaction. 


\section{Data Collection Instruments}

A survey has been made under this study as a data collection tool, and this survey consists of two parts comprising completely structured closed-end questions. The first part of the survey aims to reveal the purchasing habits and demographical characteristics of the students on getting food and beverage services, so it is prepared on a nominal scale and consists of eight questions. The second part of the survey is prepared with some assumptions to measure the brand experience, brand name, and customer satisfaction of fast-food brands.

The factor groups used in the second part of the survey consist of the factors of which validity and security are high. All questions in the second part of this survey are prepared in Likert-type scale in five stages (from $1=\mathrm{I}$ definitely agree to $5=\mathrm{I}$ definitely do not agree). There are 22 expressions in total in this part of the survey, and they are translated into Turkish by a translator who has a command of both Turkish and English and then they are translated into English again by another person who has the same characteristics of the first translator. The latest version is compared with the original expressions of the scales, and the translators exchanged ideas about the differences in their expressions. As final, the latest and the most proper language structure is given in Table 1.

Table 1

Factors in the Study and Its Original Sources

\begin{tabular}{|l|l|}
\hline Factor (expressions) & Original source \\
\hline Brand experience: & \\
This brand makes a strong impression on my visual sense or other senses. \\
I find this brand interesting in a sensory way. & \\
This brand does not appeal to my senses. & \\
This brand induces feelings and sentiments. & Brakus et al. (2009) \\
I do not have strong emotions for this brand. & \\
This brand is an emotional brand. & \\
I engage in physical actions and behaviors when I use this brand. & \\
This brand results in bodily experiences. & \\
This brand is not action-oriented. & \\
I engage in a lot of thinking when I encounter this brand. & \\
This brand does not make me think. & \\
This brand stimulates my curiosity and problem-solving. & Grace and O'Cass (2005) \\
\hline Brand name: & \\
The brand name of this service tells me a lot about what to expect. & \\
The brand name of this service tells a lot about this service. & \\
The brand name of this service means something to me. & \\
The brand name of this service sends a message to me. & \\
The brand name of this service tells me everything I need to know. & \\
\hline Customer satisfaction: & Grace and O'Cass (2005) \\
I am very satisfied with the service provided. & \\
This (service) does a good job of satisfying my needs. & \\
The service provided is very satisfactory. & \\
I believe that using this service is usually a very satisfying experience. \\
I made the right decision when I decided to use this service.
\end{tabular}

The postulates composing one of the factors of the scale and relating to the "brand experience" are cited from the studies of Brakus et al. (2009) who identified the scale of "brand experience" that is the first and most known scale developed with reference to the subject. There are four dimensions under the "brand experience" of this scale. These dimensions, in turn, are sensory dimension, affective dimension, behavioral dimension, and the intellectual dimension. There are three more expressions under each dimension, totaling 12 statements. But 
it is detected that sensory and affective perceptions are collected under one dimension after factor analysis, so the writers of this study renamed this perception as sensory-affective dimension (Brakus et al., 2009). Other factors of the scale that are "brand name" and "customer satisfaction" factors are cited from the studies of Grace and O'Cass (2005). Both factors comprise only one dimension.

\section{Results of the Confirmatory Factor Analysis (CFA) for the Scale of Brand Experience}

CFA is applied with Lisrel 8.8. Software to be able to reveal in what degree the "brand experience" scale that is used throughout this study explains the theoretical structure, since it has three sub-dimensions. It is evaluated whether the scale used in this study is applicable on the genuine factor structure of the research sample with the help of this CFA. Table 2 bearing the fit indexes of CFA results is given below.

Table 2

Fit Index Values of the Original Model

\begin{tabular}{ll}
\hline Fit criterion & Result \\
\hline Chi-square/df (132.55/44) & 3.0125 \\
Goodness of fit index (GFI) & 0.93 \\
Adjusted goodness of fix index (AGFI) & 0.88 \\
Root mean square error of approximation (RMSEA) & 0.08 \\
Comparative fit index (CFI) & 0.90 \\
Incremental fit index (IFI) & 0.90 \\
Normed fit index (NFI) & 0.86 \\
Non-normed fit index (NNFI) & 0.85 \\
\hline
\end{tabular}

The goodness of fit criterion helps to verify how relations within the model cohere with the data of study (Şimşek, 2007). The ratio of chi-square over degrees of freedom is prominent here. It is supposed to be that this ratio is 3-4. Since the chi-square value is sensitive to the magnitude of sample size, it is advised that this value should be evaluated with the other fit indexes (Özdemir \& Koruklu, 2011). The RMSEA index value that is among the other criteria is 0.08 , and the IFI shows the concordance that is acceptable. GFI is over 0.90 , and this also shows a good concordance (Okur \& Özdilek, 2012).

It is observed that the results of CFA prove that the scale used within this study is satisfactory enough and verifies the present scale structure. Cronbach Alpha calculation shows that the internal consistency coefficient of the scale is 0.853 , showing that the reliability of the scale is sufficiently high.

\section{Data Analysis}

During the evaluation of this study, Statistical Package for Social Science (SPSS) 16.0 statistics software is used. Before the analysis, the data are coded and made suitable for the analysis. At the analysis of survey results, "ratio and frequency analysis" is used, and while detecting the relationship among the variables, "correlation analysis" techniques are used. During the analysis made to reveal the relationships among the variables, parametric analysis techniques are used by taking into account the characteristics of those variables. Before applying the correlation analysis, graphical approach is used to test the data if they have normal distribution, and the skewness and kurtosis values of data are calculated. As a result of this calculation, the skewness and kurtosis values are calculated to be between -1 and +1 , and in accordance with those values, the data are accepted to be normal (Ak, 2006). It is observed that the skewness and kurtosis result of data are between acceptable range, and the group variations are equal. Since the data have normal distribution, it is also observed that Pearson correlation coefficient can be applicable for the data. 


\section{Findings and Assessment}

\section{Research Findings About the Demographic Features of Participants}

Table 3 showing performed statistic data analysis and demographic features of 300 samples who participated in the inquiry has been given below.

Table 3

Demographic Characteristics of the Students

\begin{tabular}{|c|c|c|}
\hline Gender & $N$ & $\%$ \\
\hline Female & 118 & 39.3 \\
\hline Male & 182 & 60.7 \\
\hline Total & 300 & 100.0 \\
\hline Marital status & $N$ & $\%$ \\
\hline Married & 47 & 15.7 \\
\hline Single & 252 & 84.0 \\
\hline Missing value & 1 & 0.3 \\
\hline Total & 300 & 100.0 \\
\hline Average monthly income & $N$ & $\%$ \\
\hline$\leq 500 \mathrm{TL}$ & 119 & 39.7 \\
\hline $501-1,000 \mathrm{TL}$ & 62 & 20.6 \\
\hline $1,001-1,500 \mathrm{TL}$ & 46 & 15.3 \\
\hline$\geq 1,501 \mathrm{TL}$ & 71 & 23.7 \\
\hline Missing value & 2 & 0.7 \\
\hline Total & 300 & 100.0 \\
\hline Age & $N$ & $\%$ \\
\hline$\leq 18$ & 18 & 6.0 \\
\hline $19-24$ & 200 & 66.7 \\
\hline $25-34$ & 63 & 21.0 \\
\hline$\geq 35$ & 19 & 6.3 \\
\hline Total & 300 & 100.0 \\
\hline Educational level & $N$ & $\%$ \\
\hline Undergraduate students & 200 & 66.7 \\
\hline Postgraduate students & 61 & 20.3 \\
\hline Doctoral students & 39 & 13.0 \\
\hline Total & 300 & 100.0 \\
\hline
\end{tabular}

In Table 3, 60.7\% (182 students) of participants are male and 39.3\% (118 students) of participants are female. It can be seen that participation rate of female students is lower than that of male students. The vast majority of participants (66.7\%) consist of individuals in "19-24" age rate. In another demographic characteristic, 84.0\% (252 people) of students are single and $15.7 \%$ (47 people) students are married. This result can be considered as a result of the fact that a great majority of students participating in the survey are graduate students. In the level of education, $66.7 \%$ (200 people) of participants are undergraduate students, 20.3\% (61 people) of participants are postgraduate students, and $13.0 \%$ (39 people) of participants are doctoral students. The vast majority of participants (39.7\%) stated that their average monthly income is equal to or less than $500 \mathrm{TL}$.

\section{The Research Findings About Food and Beverage Charges and Preferences of Participants}

Thirty-one point three percent (94 people) of 300 students who replied the inquiry stated that their monthly 
food-beverage charge average was "201-300 TL". In very near rate to this figure, 31\% (93 people) of 300 students stated that their monthly food-beverage charge average was " $\leq 200 \mathrm{TL}$ ", $16 \%$ of students" charge was "301-400 TL", 13\% of the students was " $\geq 501$ TL", and 8\% of students was "401-500 TL".

When replies of the question, "how many times in a month do you eat out?", are analyzed, it is seen that $39 \%$ (117 people) of the students replied that "11 times and more", 34\% (102 people) of the students replied that "6-10 times", and 27\% (81 people) of students replied that " 5 times and less".

In line of the prepared inquiry, the students who participated in the research were requested to state how many times they eat at the restaurants selected in the scope of the research. A great majority of the students (71\%, 213 people) stated that they eat " $1-5$ times" in a month in this restaurant, 19.3\% (58 people) of participants replied that they eat "6-10 times", and 9.7\% (29 people) of participants replied that they eat " 11 times and more" in this restaurant.

\section{Findings About Correlation Among the Factors}

Correlation analysis has been done to test hypotheses proposed in the scope of the research. The correlations showing relations among customer satisfaction dependant variable and brand experience (with sub-dimensions) and brand name independent variables, average, and standard deviation values are being shown in Table 4.

Table 4

Results of Bivariate Correlation Analysis Among the Variables

\begin{tabular}{|c|c|c|c|c|c|}
\hline Factor & $\begin{array}{l}\text { Customer } \\
\text { satisfaction }\end{array}$ & $\begin{array}{l}\text { Brand experience } \\
\text { (sensory-affective } \\
\text { dimension) }\end{array}$ & $\begin{array}{l}\text { Brand experience } \\
\text { (behavioral } \\
\text { dimension) }\end{array}$ & $\begin{array}{l}\text { Brand experience } \\
\text { (intellectual } \\
\text { dimension) }\end{array}$ & Brand name \\
\hline $\begin{array}{l}\text { Brand experience } \\
\text { (sensory-affective } \\
\text { dimension) }\end{array}$ & $0.448^{* *}$ & & & & \\
\hline $\begin{array}{l}\text { Brand experience } \\
\text { (behavioral dimension) }\end{array}$ & $0.353^{* *}$ & $0.349^{* *}$ & & & \\
\hline $\begin{array}{l}\text { Brand experience } \\
\text { (intellectual dimension) }\end{array}$ & $0.430^{* *}$ & $0.424^{* *}$ & $0.317^{* *}$ & & \\
\hline Brand name & $0.574^{* *}$ & $0.448^{* *}$ & $0.295^{* *}$ & $0.529^{* *}$ & \\
\hline $\bar{X}($ mean $)$ & 3.1113 & 3.0128 & 2.5567 & 2.8844 & 3.0047 \\
\hline Standard deviation & 0.90232 & 0.74693 & 0.89889 & 0.82419 & 0.78862 \\
\hline
\end{tabular}

Notes. $N=300 ;{ }^{*} p<0.05,{ }^{* *} p<0.01$.

When the relation among the variables is analyzed, it is seen that all of mentioned relations are meaningful at the level of $p<0.01$. Medium-level strong relations with a positive aspect are considered between brand experience (sub-dimensions) and brand name variables with customer satisfaction. It is seen that relation of brand name with customer satisfaction among the analyzed variables is stronger than other variables. When mentioned relations are examined, all hypotheses that were composed for the proposed model in the scope of the research were accepted as alternative hypotheses $(\mathrm{H} 1, \mathrm{H} 2, \mathrm{H} 3$, and $\mathrm{H} 4)$, and zero hypothesis was rejected.

\section{Discussion and Result}

The research has been designed to set forth the correlation between two important aspects about the brand in the research, "brand experience" and "brand name" factors with "customer satisfaction". For this purpose, research hypotheses were composed in the frame of a conceptual model which indicates mentioned relations. 
While determining the statements for "brand experience", "brand name", and "customer satisfaction" in the frame of the research, commonly accepted measuring instruments in the literature have been used.

CFA was realized to set forth conformation of used brand experience scale on sample, and it was seen that the original factor structures of the scale were valid on sample. At the end of CFA, "sensory" and "affective" brand experience dimensions that are referred at the conceptual section are correlated as a single dimension and called as "sensory-affective dimension". After accepting utility of the scale, correlation analysis was performed to determine relations among the mentioned factor groups.

Obtained findings at the end of the correlation analysis show that the factors about sensory-affective dimension, behavioral dimension, and intellectual dimension that compose sub-dimensions of brand experience have positive effects on customer satisfaction. However, it is seen that the effect of the behavioral dimension that refers brand experience on customer satisfaction is lower than other dimensions on customer satisfaction. The most important reason of this conclusion is that the brand experience that was developed by Brakus et al. (2009) was applied in a wide range from primarily technology, automobile to sport wearing and many different sectors.

In accordance with another finding that was obtained at the end of correlation, the relation of brand name with customer satisfaction is stronger than other factors. The obtained result matches with the obtained findings from the original scale (Grace \& O'Cass, 2005) that research the relation between "brand name" and "customer satisfaction" factors. Grace and O'Cass (2005) set forth that brand name has a strong positive effect on customer satisfaction in this research; they bounded the reason of this effect to the strong effect of brand name on customer expectations.

When it is considered that the enterprises in service sector can provide more limited information, it is possible to say that the brand name is an important information resource at assessment of the customers before purchasing. A good, strong brand name that was adopted by customers in food and beverage industry is closely interested in sales, profitability, customer satisfaction, and loyalty. Therefore, it is vitally important for restaurant enterprises to compose a powerful brand name sense.

A reliable brand name may make the new products in food and beverage sector more acceptable, and food manufacturers may transfer the quality, reputation, and reliability of their products to the customers easily. A powerful brand name may present quality safety and product satisfaction through providing reliability before purchasing. Sense about brand name is very important to understand the purchasing behavior of the customer (Li, Boyd, \& Pai, 2011).

The obtained results from the research support the determined hypotheses about the proposed conceptual model. It can be said that the findings of the study may provide contribution to the literature regarding both theoretical and practical aspects. But this study has some limitations too. First of all, it is not a distinctive study that does not set forth the relation between brand experience and brand name variables with customer satisfaction in literature. It provides originality, but on the other hand, it is difficult to compare the obtained findings to concern literature results. Secondly, as it is mentioned above, it provides possibility for full assessments of enterprises belonging to behavioral dimension that is one of the dimensions composing brand experience. In this regard, it is thought that the studies that will be performed with wider sample groups in future studies, adding more than one fast food enterprise and/or different sectors in tourism industry, will give more different results. Another limitation of the study is that the research was performed with students from only the determined departments of a single university. 


\section{References}

Aaker, D. (1991). Managing brand equity. New York, N.Y.: Macmillan.

Ak, B. (2006). SPSS Uygulamalı Çok Değişkenli İstatistik Teknikleri (SPSS applied multivariate statistical techniques). In Ş. Kalayc1 (Ed.), Parametrik Hipotez Testleri (Parametric hypothesis testing) (pp. 73-82). Ankara: Asil Publishing.

Alloza, A. (2008). Brand engagement and brand experience at BBVA, the transformation of a 150 years old company. Corporate Reputation Review, 11(4), 371-381.

Ambler, T., Bhattacharya, C. B., Edell, J., Keller, K. L., Lemon, K. N., \& Mittal, V. (2002). Relating brand and customer perspectives on marketing management. Journal of Service Research, 5(1), 13-25.

Andreani, F., Taniaji, T. L., \& Puspitasari, R. N. M. (2012). The impact of brand image towards loyalty with satisfaction as a mediator in McDonald's. Journal Manajemen Dan Kewirausahaan (Journal of Management and Entrepreneurship), 14(1), 64-71.

Baltas, G., \& Saridakis, C. (2009). Brand name effects, segment differences, and product characteristics: An integrated model of the car market. Journal of Product and Brand Management, 18(2), 143-151.

Brakus, J. J., Schmitt, B. H., \& Zarantonello, L. (2009). Brand experience: What is it? How is it measured? Does it affect loyalty? Journal of Marketing, 73(3), 52-68.

Chen, L. S. (2012). What drives cyber shop brand equity? An empirical evaluation of online shopping system benefit with brand experience. International Journal of Business and Information, 7(1), 81-104.

Chernatony, L., \& McDonald, M. (2006). Creating powerful brands. Oxford: Elsevier Publishing.

Dong, L. C., \& Helms, M. M. (2001). Brand name translation model: A case analysis of US brands in China. Journal of Brand Management, 9(2), 99-115.

Grace, D., \& O'Cass, A. (2005). Examining the effects of service brand communications on brand evaluation. Journal of Product and Brand Management, 14(2), 106-116.

Keller, K. L. (2003). Strategic brand management. Englewood Cliffs, N.J.: Prentice Hall.

Keller, K. L., Heckler, S. E., \& Houston, M. J. (1998). The effects of brand name suggestiveness on advertising recall. Journal of Marketing, 62(1), 48-57.

Kotler, P. (2000). Marketing management: The millennium edition. Upper Saddle River, N.J.: Prentice Hall.

Lee, H. J., \& Kang, M. S. (2012). The effect of brand experience on brand relationship quality. Academy of Marketing Studies Journal, 16(1), 87-98.

Lee, S. (2000). College student's perception and preference of brand name foodservices in university dining operations (Unpublished master thesis, Faculty of the Graduate College of the Oklahoma State University).

Li, M., Boyd, M., \& Pai, J. (2011). Factors affecting consumer perceptions of brand name food in Japan: An ordered probit analysis. The Business Review, Cambridge, 18(1), 8-13.

Marjit, S., Beladi, H., \& Kabiraj, T. (2007). Brand name collaboration and optimal tariff. Economic Modelling, 24(4), 636-647.

Nezakati, H., Kuan, Y. L., \& Asgari, O. (2011). Factors influencing customer loyalty towards fast food restaurants (pp. 12-16). Paper presented at The 2011 International Conference on Sociality and Economics Development, IPEDR Vol. 10. Singapore: IACSIT Press.

Okur, E., \& Özdilek, Y. S. (2012). Yapısal Eşitlik Modeli ile Geliştirilmiş Çevresel Tutum Ölçeği (Enhanced environmental attitude scale with structural equation modeling). Ilkögretim Online, 11(1), 85-94.

Özdemir, Y., \& Koruklu, N. (2011). Üniversite Öğrencilerinde Değerler ve Mutluluk Arasındaki İlişkinin İncelenmesi (Examination of the relationship between values and happiness in college students). Eğitim Fakültesi Dergisi (Journal of Education), 8(1), 190-210.

Pingjun, J. (2004). The role of brand name in customization decisions: A search vs experience perspective. The Journal of Product and Brand Management, 13(2/3), 73-83.

Schmitt, B. (1999). Experiential marketing. Journal of Marketing Management, 15(1-3), 53-67.

Schmitt, B. (2003). Customer experience management. New York, N.Y.: John Wiley \& Sons.

Seçkin, A., Zehir, C., \& Kitapçı, H. (2011). The effects of brand experiences, trust, and satisfaction on building brand loyalty: An empirical research on global brands. Procedia Social and Behavioral Sciences, 24, 1288-1301.

Şimşek, Ö. F. (2007). Yapısal Eşitlik Modellemesine Giriş: Temel ilkeler ve LISREL Uygulamaları (Introduction to structural equation modeling: Basic principles and applications of LISREL). Ankara: Ekinoks Publishing. 
Sondoh, S. L., Omar, M. W., Wahid, N. A., Ismail, I., \& Harun, A. (2007). The effect of brand image on overall satisfaction and loyalty intention in the context of color cosmetic. Asian Academy of Management Journal, 12(1), 83-107.

Suh, J. C., \& Yi, Y. (2006). When brand attitudes affect the customer satisfaction-loyalty relation: The moderating role of product involvement. Journal of Consumer Psychology, 16(2), 145-155.

Zarantonello, L., \& Schmitt, B. H. (2010). Using the brand experience scale to profile consumers and predict consumer behavior. Brand Management, 17(7), 532-540. 